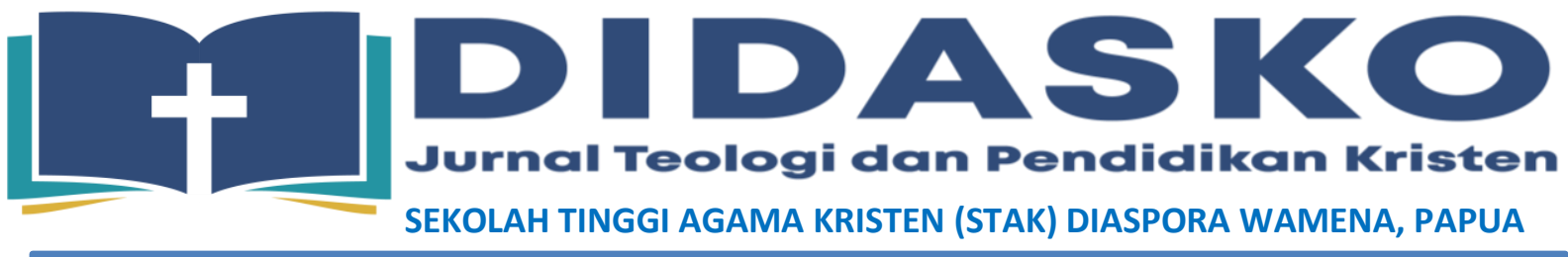

Volume 1 Nomor 1 (April 2021)

Web STAK DIASPORA Wamena: http://stakdiaspora.ac.id

Web DIDASKO: http://e-journal.stakdiaspora.ac.id/index.php/didasko/index

\title{
Integrasi Iman dan Pekerjaan sebagai Sebuah Strategi Misi
}

\author{
Tri Astuti Yeniretnowati \\ Sekolah Tinggi Teologi Ekumene, Jakarta \\ triastutiyeniretnowati2015@gmail.com \\ Yakub Hendrawan Perangin Angin \\ Sekolah Tinggi Teologi Bethel The Way, Jakarta \\ yakub.hendrawan@sttbetheltheway.ac.id
}

\section{Abstract:}

The author of the Book of Genesis describes the creation of the world by God as a work activity, and mankind as God's creation also works in paradise. Every child of God wherever he is in all his activities must be the light and salt of the world. Mission is not only an effort to preach salvation but also to present the kingdom of God in the midst of the world. Every believer must share the burden and be involved in God's mission or the ministry of God's work, because of the great commission of the Lord Jesus that must be done faithfully, continually and to the end. The response to this missionary responsibility is in accordance with their respective vocation. Everyone has different functions and roles according to God's call. Every believer must find out exactly where and how he should work for God. To fulfil His plan, God placed every believer in a specific and unique place, so that in fulfilling God's mission all believers, both spiritual and secular / professional workers have the same calling in the fulfilment of God's mission.

Key words: Vocational, Profession, Mission, Job, Vocation, Faith, Strategy

\section{Abstrak:}

Penulis Kitab Kejadian menggambarkan penciptaan dunia oleh Allah sebagai kegiatan bekerja, dan umat manusia sebagai ciptaan Allah juga bekerja di firdaus. Setiap anak Tuhan di manapun berada dalam segala kegiatannya harus menjadi terang dan garam dunia. Misi bukan hanya sebagai usaha memberitakan keselamatan tetapi juga menghadirkan Kerajaan Allah di tengah-tengah dunia. Setiap orang percaya harus turut menanggung beban dan terlibat dalam misi Allah atau pelayanan pekerjaan Tuhan, karena amanat agung Tuhan Yesus yang harus dikerjakan dengan setia, terus-menerus dan sampai akhir. Respons terhadap tanggung jawab misi ini adalah sesuai dengan panggilan masingmasing. Setiap orang memiliki fungsi dan peran yang berbeda-beda sesuai dengan panggilan Allah, setiap orang percaya harus menemukan secara tepat di mana dan bagaimana ia harus berkarya bagi Tuhan. Untuk menggenapi rencanaNya, Tuhan menempatkan setiap orang percaya pada tempat yang spesifik dan unik, sehingga dalam menggenapi misi Allah semua orang percaya baik rohaniwan maupun pekerja sekuler/profesional memiliki panggilan yang sama dalam penggenapan misi Allah.

Kata-kata kunci: Vokasi, Profesi, Misi, Pekerjaan, Panggilan, Iman, Strategi 


\section{PENDAHULUAN}

Di sepanjang sejarah, gereja pada umumnya bersikap agak ambivalen terhadap panggilan di bidang bisnis. Apa pun alasan bagi ambivalen ini, hal ini sudah menjadi masalah yang berulang-ulang, begitu kerap sampai-sampai seorang pebisnis tidak merasa nyaman berada di tengah-tengah komunitas iman mereka (Smith, 2017, p. 168).

Salah satu frasa yang paling menyinggung dan merusak jiwa dalam komunitas Kristen adalah "pekerjaan Kristiani penuh waktu". Setiap kali frasa ini digunakan ia menciptakan sebuah kesenjangan antara kehidupan doa dan aktivitas kerja orang percaya, antara cara beribadah dan cara orang percaya mencari nafkah. Salah satu pencapaian Reformasi Protestan adalah menyejajarkan kaum rohaniwan dengan orang awam. Pendeta dan tukang jagal memiliki status yang sama di hadapan salib. Ibu rumah tangga sejajar dengan penginjil. Tetapi sayangnya, kesetaraan ini telah tergerus karena kaum profesional religius telah mengklaim posisi yang lebih tinggi, menuntut hak eksklusif di bidang "pekerjaan Kristiani penuh waktu", dan memposisikan kaum awam pada pekerjaan paruh waktu (pelayanan) pada akhir minggu di bawah arahan pastoral atau kependetaan mereka. Profesionalisasi agama ini merupakan sebuah serangan terhadap integritas komunitas Kristen. Salah satu perkembangan yang memberi harapan dalam komunitas Kristen dalam dua atau tiga dekade terakhir adalah munculnya pria dan wanita yang dengan semangat mengklaim kembali kesaksian dan pelayanan kaum awam, membawa jiwa ke tempat kerja. Allah tidak memisahkan antara bahasa rohani dan bahasa sekuler, antara dunia kerja dan dunia ibadah. Mengapa kita membedakannya? (Stevens \& Ung, 2012, pp. VIII-IX).

Ada yang menyampaikan misi itu hanyalah lintas budaya, ada juga yang mengatakan semua hal yang dikerjakan di luar gereja adalah misi. Ada empat hal yang dapat menjadi kontribusi dalam memahami definisi misi, yaitu: Evangelism, Church Planting, Transformation of Society dan Cross Cultural. Apakah yang dikehendaki Allah dilakukan orang-orang percaya? Jawabannya sangat jelas, yaitu: "to do justice, to love Mercy, and to walk humbly before the Lord" (Mikha 6:8: "Hai manusia, telah diberitahukan kepadamu apa yang baik. Dan apakah yang dituntut Tuhan dari padamu: selain berlaku adil, mencintai kesetiaan, dan hidup dengan rendah hati di hadapan Allahmu?") (Pasaribu, 2012, pp. 4-7).

\section{METODE}

Analisis dilakukan dengan tinjauan pustaka, yaitu dengan cara menganalisis tentang iman Kristen dan pekerjaan sebagai sebuah kerangka konsep integrasi iman dan pekerjaan sebagai sebuah strategi misi. Sumber utama dari analisis adalah beberapa sumber relevan, hasil penelitian dari jurnal dan buku yang sesuai dengan pembahasan. Semua sumber selanjutnya dianalisis dengan cara mencermati hubungan dan kecocokan dengan tema penelitian ini. Hasil analisis selanjutnya diuraikan secara deskriptif dan sistematis. Penelitian ini diharapkan memberikan bingkai teologis bagaimana integrasi iman dan pekerjaan sebagai strategi misi (Zaluchu, 2020).

\section{PEMBAHASAN}

\section{Konsep Pekerjaan (Profesi) dan Vokasi/Panggilan}

Konsep Luther menyatakan bahwa kerja adalah suatu panggilan ilahi, di mana panggilan datang melalui posisi, umat percaya akan menemukan apa yang Allah ingin untuk dilakukan dengan waktu dan talenta yang dimiliki. Melalui berbagai panggilan yang manusia upayakan dalam aneka ragam posisi yang harus manusia emban di dunia ini, yang lapar diberi makan, yang tak berpakaian diberikan pakaian, yang sakit disembuhkan, yang tidak berpengetahuan diterangi, dan yang lemah dilindungi. Maka, dengan bekerja kita ambil bagian dalam pemeliharaan Allah yang berkelanjutan untuk umat manusia (Hardy, 2009, pp. 63-64). Bahwa Allah hadir di dalam bentuk sesama manusia yaitu Allah menjumpai umat manusia di dalam kebutuhan-kebutuhan sesama. Sebab Kristus mengidentikkan diri dengan yang papa dan yang membutuhkan (lihat Mat. 25:31-46). 
Luther menganggap bahwa Allah hadir dalam providensia-Nya dalam pekerjaan orang lain yang menopang kehidupan manusia (Hardy, 2009).

Berlawanan dengan pemikiran sebagian orang pada masa kini yang menganggap pekerjaan sebagai beban yang harus dihindari, Alkitab mengajarkan bahwa bekerja adalah sesuatu yang perlu dijalani dengan sukacita. Karena, bekerja adalah bagian yang hakiki dan luhur dari kemanusiaan kita. Mengapa demikian? Pertama, Allah adalah Allah yang bekerja. Ia sangat bersukacita ketika melihat segala hasil karya-Nya (Kej. 1:31). Ia terus bekerja hingga hari ini (Yoh. 5:17). Karena manusia diciptakan segambar dengan Allah yang bekerja, maka kita juga bekerja. Kedua, sejak awal diciptakan, manusia diperintahkan untuk bekerja, dalam rangka menunaikan mandat Ilahi yang luhur untuk mengelola bumi ciptaan Alah dan segala isinya (Kej. 1:28). Bekerja merupakan sesuatu yang mulia, yang melekat pada natur manusia sejak awal manusia diciptakan, bukan kutuk karena kejatuhannya dalam dosa (Perkantas, 2015, pp. 12-13).

Istilah vokasi adalah pengingat bahwa pekerjaan diberikan kepada orang percaya oleh pihak lain, yaitu oleh Allah yang menjadi pencipta umat percaya, dengan demikian jelaslah bahwa pekerjaan bukan allah orang percaya; pekerjaan ini diberikan kepada orang percaya sebagai karunia, sebagai sesuatu yang harus diurus. Pada akhirnya, pekerjaan tidak mendefinisikan siapa orang percaya, betapa pun pentingnya pekerjaan ini bagi orang percaya dan bagi Allah (Smith, 2017). John Cotton memberikan tiga kriteria untuk memilih suatu pekerjaan. Kriteria yang paling utama adalah bahwa "itu menjadi suatu panggilan yang dapat dibenarkan, di mana kita tidak hanya berfokus pada keuntungan pribadi, tetapi juga untuk kebaikan umum". Kriteria lainnya adalah bahwa kita berbakat untuk melakukan pekerjaan itu dan dipimpin ke arah itu oleh Allah.

Semua orang yang ingin mengikut Kristus dan menjawab panggilan-Nya harus mengejar kaitan antara bakat mereka dan panggilannya. Setiap orang percaya perlu mengetahui rancangan pribadi yang unik, yang merupakan rancangan Allah. Istilah panggilan dan vokasi harus menjadi sinonim (Guinness, 2011, pp. 71-72). Kebenaran tentang panggilan bersifat vital bagi akhir orang percaya seperti halnya bagi permulaan. Kebenaran itu adalah suatu kunci yang penting untuk menyelesaikan dengan baik karena kebenaran itu menolong orang percaya dengan tiga tantangan terbesar dari tahun-tahun terakhir kehidupan orang percaya, yaitu: Pertama, panggilan adalah pendorong yang menjaga agar dapat tetap melakukan perjalanan yang memiliki tujuan dan dengan demikian terus bertumbuh dan menjadi dewasa sampai akhir hidup. Kedua, panggilan menolong untuk menyelesaikan dengan baik karena panggilan menjaga orang percaya agar tidak mencampuradukkan berakhirnya profesi dengan berakhirnya vokasi orang percaya. Ketiga, panggilan menolong orang percaya untuk menyelesaikan dengan baik karena panggilan mendorong untuk menyerahkan seluruh hasil akhir hidup kepada Allah (Guinness, 2011).

Semua pekerjaan manusia bukan hanya sekadar pekerjaan tetapi suatu panggilan. Kata dalam bahasa Latin vocare - memanggil - adalah akar dari kata "vocation (vokasi)". Sekarang ini, kata vokasi seringkali maknanya hanyalah suatu pekerjaan, tetapi bukan seperti itu makna asalnya. Suatu pekerjaan menjadi suatu vokasi hanya jika orang lain memanggil seseorang untuk melakukannya dan seseorang itu melakukannya bagi mereka daripada bagi dirinya sendiri. Jadi pekerjaan seseorang hanya bisa menjadi suatu panggilan jika dibayangkan ulang sebagai suatu misi pelayanan bagi sesuatu yang di luar minat belaka. Sumber dari ide pekerjaan sebagai panggilan adalah Kitab Suci Kristiani.

Gerakan ekumenikal telah menyumbangkan suatu penekanan agar orang-orang Kristen menggunakan pekerjaan mereka untuk memajukan keadilan sosial dalam dunia. Martin Luther dan John Calvin, berargumen bahwa semua kerja keras, bahkan yang disebut pekerjaan sekuler, samasama merupakan panggilan dari Allah seperti halnya pelayanan para biarawan atau pendeta. Sumbersumber awal dari teologi Lutheran meletakkan penekanan khusus akan martabat semua pekerjaan, dengan memerhatikan bahwa Allah memelihara, memberi sandang, pangan, papan, dan dukungan bagi umat manusia melalui pekerjaan orang percaya sebagai umat manusia. Saat kita bekerja, seperti yang 
dikatakan oleh mereka yang ada dalam tradisi Lutheran, kita adalah "jari jemari Allah", saluran kasih pemeliharaan-Nya bagi sesama. Pemahaman ini mengangkat tujuan bekerja dari sekadar mencari nafkah menjadi mengasihi sesama dan pada saat yang sama melepaskan orang percaya dari beban yang meremukkan yaitu bekerja dengan tujuan utamanya adalah pembuktian diri. Sedangkan dalam pandangan Reform, tujuan bekerja adalah menciptakan suatu budaya yang menghormati Allah dan memampukan manusia untuk berkembang (Keller, 2017, pp. 19-20).

\section{Profesi adalah Ladang Tuhan}

Setiap orang percaya harus melakukan profesinya masing-masing untuk kemuliaan Allah, hal ini dikaitkan dengan bahwa setiap orang harus menemukan panggilan hidupnya untuk melaksanakan misi Bapa dalam hidupnya. Motivasi dan tujuan seseorang dalam bekerja yang akan menentukan suatu pekerjaan itu bersifat rohani atau duniawi. Pekerjaan Tuhan tidak hanya menyangkut pekerjaanpekerjaan yang terkait dengan gereja, tetapi setiap pekerjaan yang bertujuan menjalankan Misi Bapa itu adalah ladang pekerjaan Tuhan.

Sering terjadi ketegangan antara iman dan profesi orang-orang Kristen dan mereka tidak mampu untuk menyelesaikan hal ini, tidak banyak model yang dapat menjadi panutan dan teladan dalam menciptakan sebuah profesi di marketplace yang efektif dalam kontribusinya turut memperlebar kerajaan Allah, tidak sedikit dalam menjalankan profesinya sehari-hari mereka menilai bahwa pekerjaan mereka tidak memiliki nilai rohani, sehingga mereka menganggap bahwa profesi yang mereka jalani bukan merupakan pekerjaan yang mulia.

Marketplace sekuler dipandang sebagai sebuah upaya untuk berbagi dukungan dana bagi kegiatan yang bersifat rohani baik di dalam gereja maupun luar gereja, upah dari pekerjaan sekuler dianggap sebagai mekanisme yang penting untuk memberi dukungan keuangan kepada orang-orang yang berada di dalam pelayanan. Tetapi pekerjaan itu sendiri dipandang tidak memiliki nilai kekal sama sekali, dan banyak dari orang-orang yang betul-betul berserah memilih bergerak dan membuat komitmen di dalam hidup mereka untuk menjalankan pekerjaan yang lebih rohani.

Sebuah profesi bagi orang percaya merupakan potensi dan peluang besar dalam menjangkau jiwa-jiwa, didunia pekerjaan banyak bertemu orang-orang yang belum mengenal Tuhan, tempat kerja merupakan sarana kita untuk berdampak dan mempraktekkan cara hidup dan cara kerja seperti yang diajarkan Firman Tuhan. Di lingkungan pekerjaan kita dapat menularkan prinsip Kerajaan Allah, kita tidak dapat mengandalkan seorang rohaniawan untuk menjangkau lingkungan pekerjaan kita karena seorang pendeta tidak dapat bebas berkiprah ditempat kita bekerja.

Tempat bekerja merupakan tempat kita melakukan pengabdian untuk melayani orang lain maupun bekerja untuk mendatangkan kesejahteraan bagi orang lain, sehingga setiap profesi kita merupakan sarana yang sangat strategis untuk dijadikan sebagai ladang pelayanan bagi pekerjaan Tuhan, dengan menerapkan nilai-nilai kebenaran, menampilkan buah-buah Roh, memiliki integritas dan dedikasi yang tinggi, bertanggungjawab terhadap hal-hal kecil maupun besar, disiplin, menjaga kekudusan, menjadi sahabat bagi banyak orang, memberikan suasana yang positif ditempat kerja, sehingga banyak orang yang dimenangkan karena merasakan kasih Kristus melalui hidup kita.

\section{Integrasi Iman dan Profesi}

Profesi dan iman seringkali dipandang secara terkotak-kotak satu sama lain, sehingga berkembanglah paradigma yang memisahkan pekerjaan rohani dan duniawi. Aktivitas-aktivitas yang dianggap rohani sangat dihargai sementara aktivitas-aktivitas yang berhubungan dengan profesi kurang mendapat penerimaan sebagai bagian dari kehidupan rohani. Pekerjaan di marketplace dianggap sebagai penghalang yang dapat menghambat kita untuk tidak terlibat dalam aktivitas yang bernilai rohani seperti pelayanan, pendalaman Alkitab, persekutuan doa, penginjilan dan lain-lain. Pekerjaan itu sendiri dianggap tidak memuat nilai kekekalan. Terdapat suatu ketegangan yang belum dapat terselesaikan bagi orang-orang Kristen yang bergerak dalam marketplace karena adanya 
kerinduan terhadap pekerjaan yang bersifat rohani dan kewajiban pemenuhan pekerjaan profesinya. Dari hal ini maka tampak bahwa integrasi iman dan profesi mengalami kegagalan, sehingga mengarah kepada pemisahan antara gereja dan profesi yang menjadi pekerjaan jemaat.

Terdapat rasa frustasi dari banyak orang Kristen di marketplace karena kurangnya integrasi antara iman dan profesi ini, sering terjadi kesalahpahaman tentang konsep pelayanan, pekerjaan, dan panggilan yang telah menghalangi cara pandang mereka untuk bisa mengalami integrasi antara iman dan profesi. Harus ada jaringan antara hubungan kita dengan Tuhan dan pekerjaan kita, pekerjaan adalah panggilan kita, sebagai anak Allah kita harus berjalan dalam suatu paradigma kerja yang alkitabiah, bagaimana kita harus memahami pekerjaan kita dari sudut pandang kehendak Allah.

Lisday menghabiskan tiga tahun mewawancarai sekitar 360 orang Kristen yang telah mencapai posisi penting dalam berbagai bidang pekerjaan, bagaimana para individu ini sukses mengintegrasikan iman dan pekerjaan mereka, kesimpulannya: Ketika para pemimpin ini mendaki tangga profesional, mereka tidak pernah merendahkan identitas religius mereka. Sebenarnya, menurut banyak di antara mereka, perjalanan itu telah memperdalam iman mereka, ya, para pemimpin yang diwawancarai jatuh ke jurang yang sama dengan rekan-rekan mereka yang sekuler. Mereka rentan terhadap materialisme dan kesombongan. Namun, secara keseluruhan, mereka tetap sangat berbeda dari para pemimpin lainnya, dan alasannya adalah karena iman mereka (Sherman, 2013, p. 17).

Rasul Paulus menekankan agar kita hidup di dalam panggilan yang telah ditentukan oleh Tuhan bagi kita. "Mekarlah ditempat di mana kita ditanam". Banyak orang yang telah menerima panggilan Tuhan didunia profesi merasa kurang bermakna dalam melakukan pelayanan yang menjadi bagian dalam misinya dibandingkan dengan orang yang melayani di gereja atau menjadi misionaris yang keluar daerah untuk melakukan penginjilan karena pada intinya, nilai penginjilan sebagai sentral dan garis depan pertumbuhan gereja. Oleh karena itu misi harus menjadi integrasi antara iman dan pekerjaan yang membawa pada ketaatan terhadap Tuhan (Yonatan Alex Arifianto et al., n.d.). Namun pokok permasalahannya bukanlah bagaimana kita harus meninggalkan dunia profesi supaya dapat menjalani kehidupan iman, tetapi bagaimana kita harus menjalankan kehidupan iman di tengah kehidupan pekerjaan profesi kita masing-masing. Kehidupan rohani harus dihidupi oleh setiap orang dalam menjalankan profesinya sehari-hari.

\section{Integrasi Profesi dan Misi}

\section{Misi Panggilan Setiap Orang Percaya}

Ketika berpikir tentang globalisasi, sebagian besar orang berpikir tentang berkurangnya tembok-tembok politik, sosial, dan ekonomi yang dulu pernah begitu memisahkan negara-negara dan budaya-budaya yang berbeda. Namun ada tembok lain yang juga runtuh, sebuah tembok dalam konsep pemikiran manusia yang membawa pengaruh mendalam tentang bagaimana Gereja memahami dan menggenapi tujuan keberadaannya di dunia ini. Penghalang ini adalah "hirarki antara kehidupan rohani dan kehidupan pekerjaan" yang meskipun tidak tertulis namun telah menguasai cara berpikir banyak orang tentang bagaimana mereka berperan dalam pelayanan Kristen. Hirarki ini memandang pekerjaan tertentu lebih diperkenan Tuhan dan lebih mulia daripada pekerjaan lainnya. Misalnya, para pendeta dianggap melakukan pekerjaan yang lebih signifikan di mata Allah daripada pekerjaan seorang insinyur. Menjadi perawat adalah karir yang lebih mulia daripada menjadi seorang pramuniaga. Begitulah hirarki ini diterapkan. Implikasi dari pandangan yang sangat mengakar ini adalah seseorang yang dengan tulus berkomitmen mengikut Kristus haruslah mendapatkan pelatihan khusus, berganti karir, dan terjun ke dalam "pelayanan penuh waktu". Masalahnya adalah pandangan seperti ini tidak didukung oleh Alkitab. Sebagai seorang teolog, dalam bukunya, The Other Six Days: Vocation, Work, and Ministry in Biblical Perspective. Paul Steven mengatakan bahwa "Misi dimaksudkan untuk dijalankan oleh semua bentuk pekerjaan dan pra-pekerjaan seluruh umat Allah, jadi bukan hanya dimaksudkan bagi beberapa orang yang dipilih dan ditetapkan sebagai utusan Injil". Panggilan dan karunia rohani pribadi setiap orang mungkin berbeda, namun misi tetap merupakan tujuan utama dari seluruh tubuh Kristus. Anggapan adanya pembedaan antara pekerjaan "yang baik" 
dan "yang lebih baik" hanya akan melemahkan efektifitas Gereja, karena banyak orang Kristen yang kemudian langsung menganggap dirinya berstatus kelas dua, atau lebih buruk lagi, menjadi sepenuhnya terpisah dari keterlibatan dalam pelayanan (Rundle, 2020, pp. 533-535).

\section{Pekerjaan sebagai Misi}

Pertama, pekerjaan harus dianggap sebagai misi. Job as mission. Kalau pekerjaan itu berhubungan dengan bisnis, kita harus menganggapnya business as mission. Jika pekerjaan sebagai pembicara atau penulis, itu harus pula dianggap sebagai articles or speech with a mission. Sama halnya dengan keluarga, hal tersebut juga harus dipersiapkan sebagai family as a mission. Artinya, aktivitas itu dikerjakan bukan sekadar untuk mencari materi atau kesenangan tubuh, tetapi lebih disebabkan adanya mission yang harus diemban secara pribadi. Inilah personal mission yang ada di hati, yang dipercayai sebagai penugasan ilahi. Ini bukan sekadar exist, tetapi living it. Mission akan membuat api itu tetap bernyala karena mission adalah minyak dan api sekaligus. Tanpa mission, semua aktivitas yang dilakukan sekadar untuk mengejar imbalan semata. Entah imbalan tersebut berbentuk uang, popularitas dan bentuk lain sebagai proses transaksi (WS, 2011, pp. 26-28).

\section{Misi Holistik}

Prediksi Thom Wolf bahwa "misi di Abad ke-21 akan berlangsung utamanya dalam platform bisnis" membuktikan bahwa prediksinya tetap relevan untuk misi sekarang ini, dan bukan hanya untuk misi di luar negeri. Misi dan bisnis telah sering saling terjalin. Hal ini dilakukan di masa jemaat mulamula, Rasul Paulus adalah pembuat tenda. Bisnis juga merupakan komponen yang kuat dari gerakan kebiaran yang membawa kabar baik ke seluruh dunia. Gerakan-gerakan misi Protestan mula-mula seperti orang-orang Moravia, dan para inovator seperti William Carey juga memulai usaha mikro yang berjalan seiring dengan pelayanan Kristen. Bahkan Henry Venn dari Church Mission Society di tahun 1850-an menyarankan penggunaan usaha mikro yang dijalankan secara bersama-sama dibarengi perdagangan yang adil, sehingga misi dapat berkelanjutan dan tidak tergantung pada sumber-sumber daya asing. Seharusnya tidak mengherankan bahwa bisnis juga menjadi platform utama bagi misi di dunia Barat. Ada banyak pembicaraan tentang "Sektor Keempat" atau "Bisnis Untuk Profit" dan usaha-usaha sosial berkelanjutan yang dulunya hanya biasa dilakukan dalam misi-misi di luar negeri (Jones, 2020, p. 379).

Pelayanan di gereja dan pelayanan dalam menjalankan profesi atau pekerjaan tidak dapat dinilai mana yang lebih superior dan mana yang lebih rendah dalam ladang pelayanan Tuhan. Gereja seharusnya merupakan pendukung dalam membekali setiap jemaat untuk menjalankan profesinya sebagai bagian dalam menjalankan misi Bapa. Tidak banyak khotbah yang membahas tentang kehidupan profesi yang harus dianggap sebagai bentuk bermisi orang Kristen, sehingga bisa menghilangkan paradigma bahwa sebuah profesi dalam pekerjaan sehari-hari masih dinilai sebagai warga kelas dua dalam hal kehidupan rohani. Gereja seharusnya dapat mengutus setiap jemaat untuk melakukan profesi yang sudah Tuhan percayakan kepada masing-masing jemaat sebagai panggilan yang harus dikerjakan dengan penuh tanggung jawab sebagai bagian pelayanan misi Allah untuk turut melakukan pelebaran kerajaan Allah. Maka itu diharapkan bagi orang percaya untuk fokus pada kesaksian orang Kristen terhadap sesamanya sehingga menolong orang yang belum percaya Yesus menjadi mengenal Dia dan mempercayaiNya (Yonatan Alex Arifianto et al., 2020).

Sebuah profesi yang kita miliki adalah anugerah yang diberikan Tuhan, untuk itu setiap kita dituntut memiliki tujuan dan motivasi yang benar terhadap profesi dan pekerjaan yang Tuhan sudah percayakan kepada kita. Dalam menjalankan profesi sehari-hari harus selalu berorientasi untuk melayani orang lain dan Tuhan. Kita menjadi bagian dari kegiatan Allah dalam memberitakan kerajaan Allah kepada orang-orang yang menjadi rekan kerja, atasan maupun bawahan kita serta orang-orang yang kita temui selama bekerja. Sudah menjadi kewajiban bagi setiap orang percaya untuk mengerjakan profesi dan pekerjaannya dengan optimal, berdampak dan signifikan, serta memberikan waktu yang cukup untuk berdoa dan mencari kehendak Tuhan terhadap pekerjaan kita. 
Sebagian besar dari kita bekerja dengan maksud untuk mendapatkan uang, uang dapat menjadi tuan yang jahat dan sebagaimana ditunjukkan dalam Alkitab kita tidak dapat melayani Tuhan dan Mamon. Apabila seseorang bekerja hanya semata-mata untuk mencari uang demi memenuhi kebutuhan hidupnya dan keluarganya, maka pekerjaan yang sudah banyak menyita waktu kita itu tidak ada artinya bagi Tuhan, dan tentunya sangatlah rugi bagi kita orang percaya telah berbuat demikian karena waktu yang begitu singkat ini tidak ada maknanya untuk mempersiapkan hidup yang bersifat kekal. Maka itu prinsip penginjilan sebagai salah satu dimensinya yang esensial dan penting bagi kehidupan kekal manusia (Yonathan Alex Arifianto \& Dominggus, 2020).

Kita harus memiliki keyakinan bahwa setiap profesi yang kita miliki adalah tempat yang Tuhan pilih untuk melakukan bagian panggilan kita bagi Allah, pekerjaan yang dimiliki setiap orang percaya bukanlah suatu kebetulan. Kita harus menemukan tempat iman untuk profesi kita. Profesi adalah merupakan panggilan yang mulia, sebagai hal yang berharga, kita memiliki kedamaian dan kesukacitaan ketika kita mengetahui bahwa kita menjadi fokus kehendak Tuhan.

Banyak orang yang memiliki profesi yang sebenarnya itu adalah karunia Tuhan untuk menjalankan misi Allah di mana dia ditempatkan, namun dia membiarkan dirinya terputus hubungannya dari tanggung jawabnya kepada Tuhan terhadap profesi yang mereka miliki, mereka mencari penyelesaian terhadap ketegangan rohani dan sekuler tersebut dengan jalan melepaskan kehidupan profesi mereka dari kehidupan rohaninya. Mereka tidak mengalami integrasi antara profesi dan misi Illahi. Mereka mengabaikan panggilan bahwa melalui profesinya itu setiap orang dapat terlibat dalam pelaksanaan misi Allah secara luar biasa. Panggilan hidup setiap orang percaya harus dapat menggabungkan panggilan profesi dan pemenuhan misi Allah dalam hidupnya, tidak mudah melakukan integrasi antara profesi dan misi, namun kita harus berupaya memohon hikmat Tuhan untuk memampukan kita supaya dapat menjalankan profesi beriringan dengan pemenuhan misi Allah yang harus kita selesaikan dengan tuntas.

\section{Dasar Alkitab Tentang Pekerjaan}

Sungguh mengagumkan bahwa dalam pasal pertama Kitab Kejadian, Allah bukan hanya bekerja tetapi menemukan kesenangan di dalamnya. "Maka Allah melihat segala yang dijadikan-Nya itu, sungguh amat baik... Demikianlah diselesaikan langit dan bumi dan segala isinya" (Kej. 1:31, 2:1). Kemudian pasal kedua Kitab Kejadian menunjukkan bahwa Allah bekerja bukan hanya untuk menciptakan tetapi juga memelihara ciptaan-Nya. Inilah yang disebut oleh para teolog karya "providensia". Allah menciptakan umat manusia kemudian bekerja bagi mereka sebagai Pemelihara mereka. Dia membentuk seorang manusia (Kej. 2:7), menanami suatu taman baginya dan menyiraminya (Kej. 2:6, 8), dan membuat seorang istri baginya (Kej. 2:21-22). Bagian-bagian Alkitab lainnya menceritakan bahwa Allah meneruskan pekerjaan sebagai Pemelihara ini, menjadi dunia dengan mengairi dan mengelola tanahnya (Mzm. 104:10-22), memberi makan segala sesuatu yang diciptakan-Nya, memberi pertolongan kepada semua yang menderita dan mengurus kebutuhan segala mahluk hidup (Mzm. 145:14-16). Terakhir, pada pasal-pasal awal Kitab Kejadian Allah bukan hanya bekerja, tetapi mengutus pekerja-pekerja untuk meneruskan pekerjaan-Nya. Dalam Kejadian 1:28, Allah menyuruh umat manusia untuk "memenuhi bumi dan menaklukannya." Dalam Kejadian 2:15, Allah menempatkan umat manusia dalam taman untuk "mengusahakan dan memeliharanya" (Keller, 2017).

\section{Dipanggil untuk Berbisnis}

Di Kitab Suci, ada contoh penting tentang seseorang yang dipanggil ke bidang bisnis dan perdagangan dalam gambaran perempuan bijak di Amsal 31, dengan rujukan berulang-ulang pada profesi "pedagang" atau "saudagar": Ia serupa kapal-kapal saudagar, dari jauh ia mendatangkan makanannya. (ay.14); Ia membeli sebuah ladang yang diingininya, dan dari hasil tangannya kebun anggur ditanaminya. (ay. 16); Ia tahu bahwa pendapatannya menguntungkan. (ay. 18); Ia membuat pakaian dari lenan, dan menjualnya, ia menyerahkan ikat pinggang kepada pedagang. (ay. 24). Perempuan ini disanjung sebagai seorang saudagar atau pedagang atas kapasitasnya dalam 
menghasilkan kekayaan, menyediakan fondasi ekonomi yang solid bagi rumah tangga dan komunitasnya, serta kemurahan hatinya terhadap orang-orang yang membutuhkan. "Kejeniusannya" ada pada bidang kecerdasan ekonomi. Profil saudagar sebagai model kebijaksanaan dalam pribadi manusia adalah pengingat dua hal, Pertama, bahwa bisnis, yakni produksi barang jasa, adalah sesuatu yang tak tergantikan dalam kehidupan manusia. Kedua, profil perempuan di Amsal 31 juga menjadi pengingat bahwa ketika bisnis dilakukan dengan baik, maka bisnis itu patut beroleh pujian; bisnis menjadi sesuatu yang indah dan menakjubkan: sebuah produk yang dirancang dengan bagus, sebuah pelayanan yang dikerjakan dengan kesempurnaan dan perhatian pada detail. Dan tentu saja, ini adalah anugerah dari Allah, sebuah sarana dengan mana Allah memenuhi tujuan ilahi dunia (Smith, 2017)

Tujuan orang percaya dalam bisnis adalah untuk memajukan Kerajaan Allah dengan menunjukkan sikap seperti Kristus, menggunakan pengaruh saleh dan penatalayanan atas kekayaan dengan setia dan benar (Maiden, 2012, p. 15). Setiap orang percaya di marketplace membawa masuk sistem Kerajaan Allah untuk menghilangkan ketidakbenaran dalam dunia pekerjaan. Ketika orangorang di marketplace mendengarkan perkataan anak-anak Tuhan yang hidupnya berfondasikan pola berfikir Kerajaan Allah, pada akhirnya terjadilah transformasi, reformasi dan revolusi. Revolusi ini sudah terjadi sejak Perjanjian Lama seperti kehidupan Daniel, Nehemia dan Ester. Mereka adalah tawanan-tawanan, tetapi keadaan tidak membuat mereka berhenti menerapkan sistem Kerajaan Allah.

Matius 5:13-14 mengatakan bahwa kita harus menjadi terang dunia dan garam dunia, di manapun dan kemanapun kita melangkah harus selalu dibayang-bayangi untuk selalu menjadi terang dan garam dunia, sehingga semua orang yang berada dalam lingkungan pekerjaan kita dapat melihat Kristus dalam kehidupan kita. Kehadiran orang percaya dalam berbagai profesi yang dimilikinya harus dapat menjadi penerang ditengah-tengah kegelapan pergaulan dan budaya kerja yang tidak sehat, keberadaan dan kehadiran kita juga harus dirasakan manfaatnya dan disukai oleh banyak orang. Terang yang ada dalam diri kita harus bercahaya di depan orang, supaya mereka melihat perbuatan kita yang baik dan memuliakan Bapa yang di sorga.

Dalam Kej. 1:27-30 berisi mengenai mandat penciptaan memiliki makna orang-orang Kristen dipanggil untuk menjadi pelayan bagi bumi, mengisinya, mengembangkannya dan memeliharanya. Untuk melaksanakan mandat tersebut diperlukan orang-orang yang memiliki profesi dari berbagai bidang disiplin ilmu pengetahuan, sehingga bumi yang sudah diciptakan Tuhan dapat diisi, dipelihara dan dikembangkan dengan berbagai hal yang mendatangkan kesejahteraan dan keadilan bagi banyak orang, supaya terjadi perubahan yang baik serta maju dari jaman ke jaman sehingga semakin memberikan kemudahan kepada manusia dalam menjalankan misi Allah di bumi ini.

Amanat agung dalam Matius 28:19-20 mempunyai makna bahwa orang-orang Kristen dipanggil untuk menjadi saksi sampai akhir dari bumi ini, menjadikan semua bangsa sebagai murid. Mandat penciptaan dan Amanat Agung keduanya tergabung di dalam satu panggilan manusiawi untuk memperluas kerajaan Tuhan. Amanat Agung ini tentunya dapat dilakukan oleh setiap orang percaya kapanpun dan di manapun berada termasuk dalam kehidupan profesi masing-masing orang beriman.

Amsal 10:4 dan 21:5 memberikan pesan untuk setiap orang bekerja keras. Alasan yang menyebabkan banyak orang tidak berhasil adalah karena mereka tidak mau bekerja keras, orang-orang yang malas tidak memberikan pengaruh yang positif kepada dunia, tetapi mereka akan memberikan dampak yang negatif kepada sesama yang ada dilingkungan kerja mereka. Untuk menjadi teladan yang baik dan memberi dampak yang signifikan maka apapun profesi kita harus dikerjakan dengan rajin dan sepenuh hati.

Amsal 3:9 dan 11:25, kita semua harus memuliakan Tuhan dengan kekayaan yang kita miliki. Banyak pelaku profesi Kristen mengumpulkan kekayaan hanya untuk mengejar gaya hidup mereka, hal ini tidak memiliki nilai kekekalan sama sekali. Orang yang berorientasi pada nilai kehidupan kekal akan bekerja sesuai profesinya dengan sungguh-sungguh supaya dapat memberikan berkat yang diterimanya untuk mendukung pekerjaan penggenapan misi Allah, keputusan ini akan menjauhkan kita dari kekuatan duniawi karena hal ini merupakan pekerjaan investasi Kerajaan Allah. 
Daniel 1:8 memberikan pesan bahwa jangan takut untuk tetap teguh mempertahankan prinsipprinsip kesalehan. Daniel percaya bahwa tidak ada pekerjaan yang layak dipertahankan bila pekerjaan itu tidak menghormati Allah. Lebih baik kehilangan pekerjaan daripada kehilangan integritas kita, jangan biarkan karir profesi membelenggu kehidupan kita, Kristus bersungguh-sungguh mengatakan bahwa carilah dahulu kerjaanNya, maka Dia akan menambahkan segalanya yang kita butuhkan (Matius 6:33).

Orang-orang Kristen mempunyai karunia pribadi yang berbeda-beda, termasuk kecakapan untuk mengelola dan menolong (1 Kor. 12:28-30), dan "Layanilah seorang akan yang lain, sesuai dengan karunia yang telah diperoleh tiap-tiap orang sebagai pengurus yang baik dari kasih karunia Allah" (1 Ptr. 4:10). Allah tidak pernah memanggil orang-orang melampaui karunia yang ada pada orang tersebut; Ia memanggil orang untuk menggenapi karunia mereka.

\section{Bisnis Kerajaan Sebagai Sebuah Strategi Misi}

Orang-orang Kristen di dunia bisnis merupakan sebuah angkatan yang belum digarap yang dapat dikerahkan untuk menyebarkan Injil dan mengubah bangsa-bangsa. Para profesional Bisnis Kerajaan (adalah orang-orang bisnis yang otentik dan terampil yang menggunakan talenta mereka untuk meluaskan misi Gereja ke seluruh dunia melalui bisnis Kerajaan) (Eldred, 2008, p. 53), tidak hanya membawa berkat dari Injil, tetapi juga membawa berkat dari pekerjaan-pekerjaan produktif dan kemajuan ekonomi. Satu hal yang mengejutkan adalah bahwa banyak sekali pemerintahan yang tidak menerima misionaris Kristen pada kondisi apa pun juga, ternyata menerima pebisnis-pebisnis barat yang adalah orang-orang Kristen, asalkan orang-orang tersebut membawa ke negara-negara ini modal serta pengetahuan yang diperlukan yang bisa menciptakan peluang ekonomi yang lebih besar bagi orang-orang di negara tersebut. Sehingga ada sepuluh alasan mengapa orang-orang yang terlibat dalam Bisnis Kerajaan (adalah usaha-usaha bisnis yang berorientasi pada keuntungan yang dibuat untuk memudahkan transformasi yang dilakukan Tuhan terhadap bangsa-bangsa dan negara-negara) (Eldred, 2008), merupakan orang-orang yang secara strategis sangat penting dan efektif, yaitu: Pertama, merupakan sebuah model bagi misi yang sepenuhnya; Kedua, membawa keahlian, teknologi dan modal yang sangat dibutuhkan; Ketiga, menciptakan pekerjaan; Keempat, membangun perekonomian lokal dan memberkati bangsa. Kelima, memberikan akses ke banyak lokasi; Keenam, menyampaikan Injil melalui kata-kata; Ketujuh, menunjukkan Injil dengan perbuatan; Kedelapan, memungkinkan pendanaan bagi gereja lokal; Kesembilan, dapat menjadi mitra yang tak ternilai bagi upaya-upaya misi lainnya; dan Kesepuluh, bergantung pada sumber yang hanya sedikit sekali digunakan namun merupakan sumber yang sangat berguna di dalam Gereja. Bisnis Kerajaan tidak terbatas pada orangorang yang menjalankan perusahaan besar. Setiap orang yang memiliki pengalaman bisnis dapat memberikan sumbangan tak terbatas kepada wadah pengetahuan bisnis di kebanyakan negara yang sedang berkembang (Eldred, 2008)

\section{Orang Beriman Harus Menjadi Pekerja Terbaik (Profesional)}

Orang Kristen seharusnya menjadi pekerja yang benar-benar terbaik. Orang Kristen harus menjadi pekerja paling giat di antara semua pekerja yang ada. Karena Alkitab dengan jelas dan berulang-ulang mendukung sudut pandang ini, yaitu: “Apapun juga yang kamu perbuat, perbuatlah dengan segenap hatimu seperti untuk Tuhan dan bukan untuk manusia. Kamu tahu, bahwa dari Tuhanlah kamu akan menerima bagian yang ditentukan bagimu sebagai upah. Kristus adalah tuan dan kamu hamba-Nya (Kol. 3:23-24)" (Gelsinger, 2007, p. 155) Dalam kaitannya terhadap misi, maka pesan untuk mencari jiwa atau bermisi dimasukkan ke dalam teks Amanat Agung dan dijadikan teks untuk pekabaran Injil sebagai bagian dari motivasi dan panggilan sebagai orang percaya baik dalam pekerjaan atau hal yang lainnya dapat menjadi prioritas dilakukan sebab orang percaya yang harus melakukan dengan ketaatan apa yang telah diterimanya dalam menunaikan tugas dan tanggung jawabnya sebagai pribadi yang telah menerima keselamatan (Yonatan Alex Arifianto, 2020). 


\section{KESIMPULAN}

Gereja membutuhkan banyak sekali orang percaya kepada Kristus, yaitu orang Kristen profesional guna ikut serta dalam kegerakan penginjilan, seperti dokter dan tenaga medis lainnya, ahli teknik, ilmuwan, pebisnis, petani, olahragawan, wartawan, guru dan ahli-ahli lainnya dari berbagai bidang, tentmaker yang dapat mengintegrasikan antara pekerjaan dan imannya sebagaimana yang dilakukan oleh Rasul Paulus. Rasul Paulus sangat berminat terhadap orang-orang yang belum terjangkau (Roma 15:20). Pelayanan marketplace membagikan keyakinan bahwa bisnis yang dikelola dengan baik dapat dengan sendirinya memberi dampak kepada masyarakat. Fokus pada pelayanan kepada orang-orang yang ada di sekitar.

Bekerja merupakan respon umat manusia terhadap panggilan Allah, Allah memberikan mandat budaya dan menempatkan setiap umat yang percaya kepada-Nya untuk mengupayakan kesejahteraan dan mengembangkan potensi-potensi ciptaan Allah bagi hormat dan kemuliaan-Nya. Implikasi dari integrasi antara iman Kristen dan pekerjaan atau profesi kita adalah, walaupun Allah bekerja bagi umat-Nya sebagai Pemelihara, umat yang percaya kepada-Nya juga bekerja bagi-Nya, bahkan Allah bekerja melalui umat-Nya.

Manusia yang diciptakan menurut gambar dan rupa Allah harus bekerja untuk menunjukkan kemuliaan Allah di dunia. Melalui sebuah profesi, kita dapat menyatakan kasih Allah, keadilan Allah, kebenaran Allah, seluruh atribut Allah dalam diri seorang gambar dan rupa Allah. Profesi yang berkenan kepada Allah memiliki nilai kekal, baik dalam tujuan profesi maupun hasil karya dari sebuah profesi tersebut. Apapun pekerjaan maupun profesi seseorang bila dikerjakan dengan tujuan dan motivasi yang sesuai maksud dan kehendak Allah memiliki nilai pelayanan yang sangat mulia sebagai bagian dalam menggenapkan misi Allah bagi dunia. 


\section{DAFTAR PUSTAKA}

Arifianto, Yonatan Alex. (2020). Peran Kepemimpinan Misi Paulus dan Implikasinya bagi Pemimpin Misi Masa Kini. Jurnal Teologi Amreta (ISSN: 2599-3100), 4(1), 67-88.

Arifianto, Yonatan Alex, Oktavia, K., \& Dwikoryanto, M. I. T. (2020). Studi Teologis Prinsip Penginjilan Paulus dalam 1 Korintus 9:16. LOGIA: Jurnal Teologi Pentakosta, 2(1), 22-41.

Arifianto, Yonatan Alex, Triposa, R., \& Lembongan, P. K. (n.d.). Studi Alkitab tentang Misi dan Pemuridan dalam Amanat Agung dan Implikasinya Bagi Kehidupan Kristen Masa Kini. Diegesis.

Arifianto, Yonathan Alex, \& Dominggus, D. (2020). Deskripsi Teologi Paulus Tentang Misi dalam Roma 1: 16-17. ILLUMINATE: Jurnal Teologi Dan Pendidikan Kristiani, 3(2), 70-83.

Eldred, K. (2008). God Is At Work (1st ed.). Nafiri Gabriel.

Gelsinger, P. (2007). Balanced Life: Menyeimbangkan Iman, Keluarga dan Karier (1st ed.). Andi Offset.

Guinness, O. (2011). The Call (1st ed.). Pionir Jaya.

Hardy, L. (2009). Karier: Panggilan atau Pilihan? (1st ed.). Yayasan Pancar Pijar Alkitab.

Jones, A. (2020). Misi Kembali Ke Rumah. In R. D. Winter \& S. C. Hawthorne (Eds.), Perspectives on the World Christian Movement (2nd ed.). Perspectives Indonesia.

Keller, T. (2017). Apakah Pekerjaan Anda Bagian Dari Pekerjaan Allah? (4th ed.). Literatur Perkantas Jawa Timur.

Maiden, M. (2012). The Seven Mountains (1st ed.). Andi Offset.

Pasaribu, R. (2012). Misi Allah. In Mission Possible (1st ed.). Literatur Perkantas.

Perkantas, T. S. (2015). Bekerja Tanpa Kehilangan Visi (4th ed.). Literatur Perkantas.

Rundle, S. (2020). Mengembalikan Peran Bisnis di Dalam Misi. In R. D. Winter \& S. C. Hawthorne (Eds.), Perspectives on the World Christian Movement (2nd ed.). Perspectives Indonesia.

Sherman, A. L. (2013). Kingdom Calling: Vocational Stewardship For The Common Good (1st ed.). Literatur Perkantas.

Smith, G. T. (2017). Courage and Calling (1st ed.). Literatur Perkantas Jawa Timur.

Stevens, R. P., \& Ung, A. (2012). Taking Your Soul To Work (1st ed.). Literatur Perkantas.

WS, P. B. (2011). Balancing Your Life: Menyelaraskan Prestasi, Keluarga, dan Kehidupan Rohani (4th ed.). Inspirasi.

Zaluchu, S. E. (2020). Struktur Artikel untuk Jurnal Ilmiah dan Teknik Penulisannya. In S. E. Zaluchu (Ed.), Strategi Menulis Jurnal Untuk Ilmu Teologi (1st ed., pp. 1-21). Golden Gate Publishing Semarang. 